УДК 636.4.082

(C) 2015

Войтенко С. Л., доктор сільськогосподарських наук

Полтавська державна аграрна академія

\title{
ГЕНОФОНД ПОРІД ТВАРИН ПОЛТАВЩИНИ ТА РИЗИКИ ВТРАТИ МІСЦЕВИХ ПОПУЛЯЦІЙ
}

\section{Рецензент - доктор сільськогосподарських наук А. А. Полішук}

У статті викладені результати паспортизації суб' сктів племінної справи у молочному скотарстві Полтавської області та обстеження стад місиевих нечисленних порід тварин. Виявлено, шзо племінні господарства по розведенню великої рогатої худоби молочних порід відрізняються між собою як за рівнем селекційно-племінної роботи, так $i$ за кількістю корів y стадах та їх продуктивністю. Значна кількість господарств не має автоматизованої системи ведення племінного обліку, щзо унеможливлює ефективний підбір тварин, оцінювання їх за низкою ознак і підвищення продуктивності поколінь. Аналіз галузі підтвердив, щуо в області в категорії суб 'єктів племінної справи молочного скотарства знаходяться господарства, у яких є значні порушення із відтворенням стада, не обтрунтоване використання певних бугаїв-плідників, високі витрати кормів на виробничтво молока. Було запропоновано проводити селекцію в стадах у відповідності до розроблених програм з конкретними породами під контролем наукових установ. Обстеження стад локальних порід Полтавщини, серед яких миргородська порода свиней, сокільська порода овець $і$ полтавська глиняста породи курей, засвідчило їх критичний стан щзодо численності з постійним скороченням популяцій у результаті відсутності попиту на племінну продукцію. Збереження даних популяцій не можливе без державних дотащій, а їх зникнення співвідносне втраті національного надбання й культурної цінності.

Ключові слова: молочне скотарство, паспортизаиія стад, продуктивність тварин, локальні породи тварин.

Постановка проблеми. Виробництво продукції тваринництва в сучасних ринкових умовах узгоджується з постійною інтенсифікацією галузі, створенням високопродуктивних порід, впровадженням прогресивних технологій, кормовиробництвом тощо. Породи сільськогосподарських тварин, які використовуються для виробництва продукції, різняться між собою за видовою належністю, тривалістю використання, якістю i кількістю продукції, здатністю розмножуватися у відповідних еколого-економічних умовах і забезпечувати потреби населення. Якщо порода, як засіб виробництва, перестає задовольняти попит споживачів на той чи інший вид продукції, іï замінюють на іншу, або на їі основі створюють популяцію з бажаними ознаками продуктивності. Саме такий підхід був покладений в основу породоутворюючого процесу в Україні, який мав місце в кінці минулого століття й завершився створенням ряду нових порід великої рогатої худоби молочного i м'ясного напряму продуктивності, свиней, овець, коней, птиці. Проте питання доцільності поглинання місцевих сільськогосподарських порід, які мали добру адаптованість, пристосованість до умов утримання й годівлі, високу якість продукції, більш продуктивними зарубіжними породами, до цього часу $є$ дискусійним. Основними запереченнями проти поглинання локальних порід вважають втрату національного надбання, культурної цінності, яку залишили нам у спадок попередні покоління науковців і виробничників, а також те, що сучасні породи не завжди проявляють бажану продуктивність і за низкою ознак $є$ кращими від тих локальних порід, на основі яких вони були створені.

Полтавщина, яка наразі відноситься до однієї 3 провідних областей України за розвитком галузі тваринництва, в історичному аспекті мала свої місцеві локальні популяції тварин, які майже втрачені. Частина цих порід, а саме: свині миргородської породи, вівці сокільської породи та кури полтавської глинястої породи ще розводяться в окремих господарствах області, але ці осередки вже не впливають на розвиток галузі тваринництва й своїм збереженням завдячують здебільшого лише керівництву приватних чи державних сільськогосподарських підприємств. Для визначення дійсного стану локальних місцевих порід Полтавщини у 2014 році була проведена інвентаризація стад вищевказаних порід, які утримуються в племінних господарствах області. Крім того, з метою визначення ефективності розведення сучасних порід великої рогатої худоби молочного напряму продуктивності в суб'єктах племінної справи молочного скотарства області був проведений аналіз господарськоекономічної діяльності племінних господарств, який включав молочну продуктивність корів, їх відтворну здатність, якість бугаїв-плідників, рентабельність виробництва молока та інші чинники. 


\section{СІЛЬСЬКЕ ГОСПОДАРСТВО. ТВАРИННИЦТВО}

\begin{abstract}
Аналіз останніх досліджень і публікацій, у яких започатковано розв'язання проблеми.
\end{abstract} На сучасному етапі економічного розвитку України вітчизняне молочне скотарство повинно бути конкурентоспроможним, рентабельним та забезпечувати продовольчу незалежність країни. Вчені продовжують проводити роботу з удосконалення порід великої рогатої худоби шляхом підвищення продуктивного потенціалу тварин, використовуючи принципи великомасштабної селекції молочної худоби, комп'ютерної техніки, створення комфортних умов для утримання тварин та прояву їх генетичного потенціалу, використання біотехнологічних методів відтворення тощо. Проте пошук ефективних методів, спрямованих на прискорення темпів генетичного поліпшення порід за адекватних змін умов зовнішнього середовища, залишається актуальною проблемою сьогодення. Як свідчить досвід країн 3 розвинутим молочним скотарством, завдяки впровадженню в практику принципів великомасштабної селекції молочної худоби вдалося досягти середньорічного генетичного прогресу - до 120 кг молока на корову в рік [4]. За даними вітчизняних вчених $[2,5]$, у популяціях вітчизняних порід молочного напряму продуктивності величина щорічного генетичного прогресу змінюється у залежності від породи, генотипу, віку та інших гено- та паратипових чинників. 3 урахуванням чого актуальними є пошуки методів підвищення темпів генетичного прогресу продуктивності великої рогатої худоби та оптимізації впливу паратипових факторів на формування високопродуктивних стад молочної худоби.

Одночасно на фоні створення нових, більш високопродуктивних порід сільськогосподарських тварин в агропромисловому комплексі прогресує проблема витіснення i навіть зникнення локальних порід, які перестали задовольняти попит на той чи інший вид продукції. За даними ФАО, аналіз 6 видів і 877 порід із 36 країн Європи вказує, що 452 породи знаходяться у критичному стані [3], але це не зупиняє антропологічний вплив людини, який охоплює дедалі більше нових територій, витісняючи 3 поверхні Землі цілі види. Оцінювання генетичних ресурсів вказує, що внесок України в цей процес досить суттєвий. В Україні назавжди зникли германо-бессарабська, ногайська i стрелецька породи коней, тарпан, свині придніпровської, кролевецької, подільської породних груп й українська локальна популяція європейської коротковухої свині, чорно-ряба подільська порода, гуцульська i українська білоспинна популяції великої рогатої худоби, породи овець чунтук, мазаєвський меринос i решетилівська та дві породи кіз - асканійська мохерова і кримська [6].

Зараз в Україні в критичному стані щодо чисельності знаходяться наші національні надбання, породи сільськогосподарських тварин, серед яких: сіра українська і білоголова українська породи великої рогатої худоби, українська степова біла, українська степова ряба та миргородська породи свиней, сокільська порода овець, гуцульська порода коней і багато порід птиці [1]. Допустити втрату цих ресурсів означає проявити неповагу до минулих і майбутніх поколінь.

3 урахуванням вищевикладеного, вважаємо за доцільне проведення моніторингу стану галузі молочного скотарства та нечисленних вітчизняних порід свиней, овець і курей на Полтавщині 3 можливістю підвищення генетичного потенціалу корів та розробки методології збереження локальних популяцій.

Метою досліджень був аналіз галузі молочного скотарства Полтавської області та місцевих нечисленних порід тварин у суб'єктах племінної справи.

У завдання досліджень входило проведення паспортизації племінних стад великої рогатої худоби молочного напряму продуктивності за розробленими анкетами, а також інвентаризація стад локальних порід 3 визначенням низки кількісних і якісних ознак.

Матеріали і методи досліджень. Аналіз стану галузі молочного скотарства проводили за численністю поголів'я корів, їх чистопородністю, молочною продуктивністю, відтворною здатністю, які були розраховані в господарствах за існуючих методик у скотарстві, використанням відповідних ліній і плідників, наявності автоматизованої системи ведення племінної роботи тощо. Оцінювання стану локальних нечисленних порід здійснювали за розробленою методикою та анкетами експедиційного обстеження. Основний акцент був зроблений на визначенні кількості маток і плідників, характеристиці тварин за основними господарсько-корисними ознаками, динаміці зміни поголів'я, рентабельності виробництва продукції та іншими чинниками.

Результати досліджень. Україна на даному етапі розвитку галузі тваринництва представлена багатьма видами й породами, серед яких більше 25 порід великої рогатої худоби молочного і м'ясного напряму продуктивності, 12 порід свиней, 13 порід коней, 7 порід і більше десяти породних типів овець, досить багато порід гусей, качок, індиків, риби тощо. Полтавська область, у свою чергу, останні роки зосереджує увагу на розведенні таких порід тварин: великої рогатої 


\section{СІЛЬСЬКЕ ГОСПОДАРСТВО. ТВАРИННИЦТВО}

худоби молочного напряму продуктивності - айрширська, голштин європейської селекції, симентальська, українська чорно-ряба і українська червоно-ряба; великої рогатої худоби м'ясного напряму продуктивності - абердин-ангус і українська м'ясна; свиней великої білої породи, ландрас, червоної білопоясої, миргородської і великої чорної порід; овець сокільської породи і прекос, а також таврійського типу асканійської тонкорунної породи; коней орловської і російської рисистих порід, української верхової і новоолександрівської ваговозної порід; птицю яєчних кросів та полтавської глинястої породи, качки кросу «Благоварський», гусей великої сірої породи, бджіл української степової породи, риби - білий і строкатий товстолобик, рамчастий і лускатий короп.

Не вдаючись до оцінювання усіх порід сільськогосподарських тварин, яких розводять на Полтавщині, акцентуємо увагу лише на галузі молочного скотарства, яка була детально проаналізована в суб'єктах племінної справи у тваринництві. Слід зазначити, що серед 34 племінних господарств галузі молочного скотарства Полтавської області, переважна більшість розводить українську чорнорябу молочну породу. Поголів'я корів у стадах суб'єктів племінної справи молочного скотарства області варіює від 40 голів до 1128 голів за досить високої мінливості надоїв на корову за 305 днів лактації: від 4342 кг до 9000 кг. Введення корів у стадо узгоджується із розширенням стада, вибракуванням менш продуктивних та тих, що не відповідають технологічним вимогам виробництва молока. Загалом у племінних стадах області у 2013 році кількість введених корів варіювала у межах 17,5-50,0\%.

Кількість осіменінь для запліднення однієї корови чи телиці, або індекс осіменіння, визначається кількістю осіменінь і повинен становити 1,2-2. У племінних господарствах області кількість осіменінь для запліднення однієї корови чи телиці мало межі 1,4-24. Водночас найменшою кількість запліднень на одне плідне була в СТОВ АФ «Оржицька», СТОВ «Воскобійники», СТОВ «Перемога».

Для осіменіння корів і телиць використовувалася сперма бугаїв-плідників, які мають селекційний індекс (CI) +180-+2035. Вважається, чим вищий селекційний індекс плідника, тим він має вищу здатність передавати свою продуктивність дочкам, тим самим поліпшуючи якість стада. Проте в більшості племінних господарств області використовували бугаїв-плідників, племінна цінність яких була низькою, що не сприятиме підвищенню продуктивності у поколіннях. Приміром, за надоїв на корову впродовж лактації 4468 кг використовують бугаїв-плідників, які мають СI +180 i +403; 6936 кг молока відповідно, СІ +559 і +986; 7500 кг молока - CI +518; 9000 кг - CI +1284 тощо. На ринку реалізації сперми в області працюють ПАТ «Полтаваплемсервіс», Лубенське племпідприємство, ТОВ «Сімекс Альянс Україна», ПП «Генетика і селекція», ТОВ «Українські ферми», ПрАТ «Українська генетична компанія» i ABS TOB «Генус-Україна», які пропонують сперму бугаїв-плідників усіх порід як вітчизняного, так і закордонного походження, але надої на корову вище 7000 кг мають лише окремі племінні господарства. Заслуговує на увагу підбір з метою підвищення молочної продуктивності корів у стадах таких господарств, де використовуються плідники 3 високими CI, а саме: ТОВ «Бурат-Агро», ПАФ «Україна», ПСП «Дружба», ДП «ДГ «Степне» (поставляє сперму «Полтаваплемсервіс»), ТОВ «АФ ім. Довженка» (поставляє сперму ТОВ «Сімекс Альянс Україна»), ПП «Агроекологія» (постачає сперму ПрАТ «Українська генетична компанія»), ТОВ «Промінь-Приват» (ТОВ «Українські ферми»), ТОВ «Леляківське» ( ПП «Генетика і селекція») та СВК «Перемога» (ТОВ «Лубенське племпідприємство»).

У відповідності до Положення про присвоєння відповідних статусів суб'єктам племінної справи у тваринництві від 27.05.2003 року за № 129/41 (зі змінами і доповненнями з 2001 року) однією 3 обов'язкових вимог діяльності племінного господарства по розведенню великої рогатої худоби молочних порід $\epsilon$ ведення автоматизованого індивідуального обліку продуктивних і племінних якостей тварин. Але в області більша половина племінних господарств різної потужності не має автоматизованої системи ведення племінного обліку, що унеможливлює оцінювання тварин за низкою ознак, ефективністю селекції в стадах та підвищення продуктивності. В середньому на 1 ц молока витрачають 1,1-1,5 ц одиниць корму за досить високої рентабельності виробництва молока.

Характеризуючи галузь молочного скотарства в Полтавській області за низкою чинників зроблено висновок про можливість чистопородного розведення порід, оскільки є сприятливі умови для відтворення тварини за рахунок завезення сперми плідників чи племінного поголів'я тієї чи іншої породи. Але в Полтавській області є породи, які перебувають на грані зникнення й, не дивлячись на положення Законів України «Про племінне тваринництво», «Про державну підтримку сільського господарства в Україні», ратифіковану Конвенцію щодо збереження біологічного різноманіття, розроблені методології, стратегії та численні програми, проблема їх розведення не 


\section{СІЛЬСЬКЕ ГОСПОДАРСТВО. ТВАРИННИЦТВО}

вирішена, а чисельність щороку скорочується й доходить до критичного стану.

Інвентаризація стад локальних порід Полтавщини, а саме: миргородської породи свиней, сокільської породи овець та курей полтавської глинястої породи свідчить, що вони дійсно знаходяться в критичному стані щодо чисельності поголів'я, але можуть його розширити за рахунок чистопородного розведення. Так, аналіз стану свиней миргородської породи, яку розводять у ДП «ДГ ім. Декабристів» Миргородського району, засвідчив, що влітку 2014 року у стаді племінного заводу утримувалося 175 основних чистопородних свиноматок, які відносилися до 11 родин, а також 21 основних кнурів, які належали до 7 ліній.

В динаміці останніх 2011-2014 років кількість основних кнурів скоротилася на 10 голів або $6,7 \%$, а основних свиноматок - на 25 голів, або $12,5 \%$, жива маса кнурів за 24 місяці збільшилася на 10 кг і становила 275 кг, а свиноматок після першого опоросу залишається на одному рівні - 191 кг. Одночасно слід вказати на невисокі показники багатоплідності свиноматок та їх неефективне використання за чистопородного розведення протягом року. Протягом останніх 2-3 років в господарстві не було реалізації племінної продукції, що змушує чистопородних тварин здавати на забій через збитковість розведення свиней миргородської породи. Враховуючи збитковість одержання та реалізації племінної продукції, в господарстві впровадили потоково-цехову технологію виробництва свинини на промисловій основі, коли свиноматок миргородської породи використовують для схрещування із кнурами різних генотипів. Стан породи критичний, оскільки чистопородне розведення свиней миргородської породи, поза племінного заводу ім. Декабристів Полтавської області, здійснює тільки ФГ «Аміла» Волинської області.

Оцінювання стану овець сокільської породи у 2014 році була проведена лише в СК «Радянський» Кобеляцького району Полтавської області, оскільки навесні поточного року перестав існувати єдиний племінний завод в Україні і нашій області по розведенню даної породи - «Здобуток». Станом на 01.01.2014 року в стаді СК «Радянський» утримувалося 156 овець сокільської породи, серед яких 4 барани-плідники і 73 голів вівцематки.

Барани-плідники мали вік 8-13 років і належали до ліній 1125 і 8184. Вихід ягнят на 100 ярок становив 100 голів за середньої живої маси ягнят під час відлучення - 16 кг. Для одержання смушків з приплоду було забито 34 \% ягнят, а решта залишена для вирощування. Середній настриг вовни з однієї голови становив 1,9 кг. Водночас ні вовна, ні шкурки забитих ягнят останні роки не реалізуються, що призводить до збитковості галузі вівчарства в господарстві, яка в минулому році становила 6 тисяч гривень. Вівці утримуються за класичною технологією, використовуючи влітку випас. Порода знаходиться в критичному стані, оскільки крім даного племінного господарства незначну кількість овець сокільської породи утримують ще в одному господарстві Харківської області.

Під час інвентаризації курей полтавської глинястої породи в племінному птахорепродукторі СВК «Батьківщина» Котелевського району Полтавської області станом на 01.01.2014 року було встановлено, що в стаді утримувалося 6497 голів птиці, серед яких 3000 курей-несушок та 300 півнів селекції Інституту птахівництва НААН.

У динаміці 2011-2013 років відбулося збільшення поголів'я птиці на 801 голову, але це єдине стадо в Україні й питання його чистопородного розведення без можливості завезення селекційного матеріалу стоїть дуже гостро. Статевої зрілості (вік знесення першого яйця) курочки батьківського стада в господарстві набували за 165-168 днів. У 2013 році на середню несучку було одержано 186 шт. яєць, маса яких 6263 грама. Збереженість птиці достатньо висока i майже відповідає стандарту породи - 90-92 \%. Птиця утримується в приміщенні за класичною технологією та вільного випасання на прифермерській території. В останні 2-3 роки обмін маточного поголів'я не проводиться, а відтворення здійснюється за рахунок власного стада. Рентабельність виробництва яєць - $15,5 \%$, хоча в динаміці 2011-2013 років відмічена тенденція до зниження прибутковості їх виробництва.

Висновок. Інвентаризація стад локальних порід Полтавщини вказує на проблеми із реалізацією племінної та товарної продукції, яку від них отримують, що в свою чергу призводить до збитковості їх розведення й бажання їх позбутися. Сдиним виходом 3 цієї ситуації вбачається державна дотація, яка відшкодовувала б витрати на утримання тварин в стадах, але вона мабуть не реальна, хоча й передбачена законодавчою базою в галузі тваринництва України.

Як підсумок паспортизації племінних стад по розведенню великої рогатої худоби молочного напряму продуктивності слід вказати, що попри деякі нюанси більша частина племінних господарств області відповідає встановленим законодавчою базою вимогам, пред'явленим до суб'єктів племінної справи в галузі молочного скотарства. 
А ті, що не відповідають, не повинні перебувати в категорії племінних господарств та реалізувати племінну продукцію.

Особливо хотілося б наголосити на необхідності ведення селекційно-племінної роботи в суб'єктах племінної справи у відповідності до розроблених

\section{БІБЛІОГРАФІЯ}

1. Войтенко С. Л. Генофонд сільськогосподарських порід тварин / С. Л. Войтенко : збірник тез науково-практичної конференції професорсько-викладацького складу, 13-14 травня 2014. Полтава, 2014. - С. 226-228.

2. Генетико-селекційний моніторинг у молочному скотарстві / [М. В. Зубець, В. П. Буркат, М. Я. Єфіменко та ін.] ; за ред. В. П. Бурката. К. : Аграрна наука, 1999. - 88 с.

3. Глобальный план действий в области генетических ресурсов животных и Интерлакенская Декларация о генетических ресурсах животных / Комиссия по генетическим ресурсам в сфере продовольствия и сел. хоз-ва. - Рим : ФАО, 2008. - науковими установами Програм селекційноплемінної роботи по кожній породі. Інакше в господарствах відбувається лише виробництво молока, для чого не потрібно мати статус суб'єкта племінної справи в галузі молочного скотарства.

$37 \mathrm{c}$.

4. Степанов Д. В. Молочная продуктивность голштинизированого черно-пестрого скота / Д. В. Степанов, Н. Д. Родина // Зоотехния. 2006. - №11. - С. 5-9.

5. Рудик I. А. Генетико-економічна оцінка різних систем використання бугаїв-плідників : зб. наук. праць / I. А. Рудик // Вісник Білоцерківського ДАУ. - Біла Церква, 1997. - Вип. 2. Ч. 1. - С. 209-212.

6. Mason I. L. A world dictionary of live stock breeds, types and varieties / I. L. Mason. - Wallingford, Oxon, UK : CAB International, 1996. - 273 p. 